Review

\title{
Overview of Scorpion Species from China and Their Toxins
}

\section{Zhijian Cao ${ }^{\dagger}$, Zhiyong Di ${ }^{\dagger}$, Yingliang Wu * and Wenxin $\mathrm{Li}$ *}

State Key Laboratory of Virology, College of Life Sciences, Wuhan University, Wuhan 430072, China; E-Mails: zjcao@whu.edu.cn (Z.C.); scorpionking@whu.edu.cn (Z.D.)

$\dagger$ These authors contributed equally to this work.

* Authors to whom correspondence should be addressed; E-Mails: ylwu@whu.edu.cn (Y.W.); liwxlab@whu.edu.cn (W.L.); Tel.: 086-27-68756746.

Received: 13 December 2013; in revised form: 16 January 2014 / Accepted: 18 January 2014 / Published: 26 February 2014

\begin{abstract}
Scorpions are one of the most ancient groups of terrestrial animals. They have maintained a steady morphology over more than 400 million years of evolution. Their venom arsenals for capturing prey and defending against predators may play a critical role in their ancient and conservative appearance. In the current review, we present the scorpion fauna of China: 53 species covering five families and 12 genera. We also systematically list toxins or genes from Chinese scorpion species, involving eight species covering four families. Furthermore, we review the diverse functions of typical toxins from Chinese scorpion species, involving $\mathrm{Na}^{+}$channel modulators, $\mathrm{K}^{+}$channel blockers, antimicrobial peptides and protease inhibitors. Using scorpion species and their toxins from China as an example, we build the bridge between scorpion species and their toxins, which helps us to understand the molecular and functional diversity of scorpion venom arsenal, the dynamic and functional evolution of scorpion toxins, and the potential relationships of scorpion species and their toxins.
\end{abstract}

Keywords: scorpion; fauna; toxin; function; evolution; relationship

Scorpions are one of the most ancient groups of terrestrial animals, belonging to the class Arachnida within the phylum Arthropoda. Scorpions represent a basal branch of arachnids and have a relatively distant relationship with Acari (mites) and Araneae (spiders), the other two groups of the class Arachnida. Thus, scorpions have an important phylogenetic position within the phylum Arthropoda and the class 
Arachnida (Figure 1) [1]. There are approximately 15 families, 197 genera and 2,089 species recorded in the world except for Greenland and Antarctica (http://www.ntnu.no/ub/scorpion-files/index.php, accessed on 8 October 2013).

Figure 1. Phylogenetic position of the scorpiones within the class Arachnida [1].

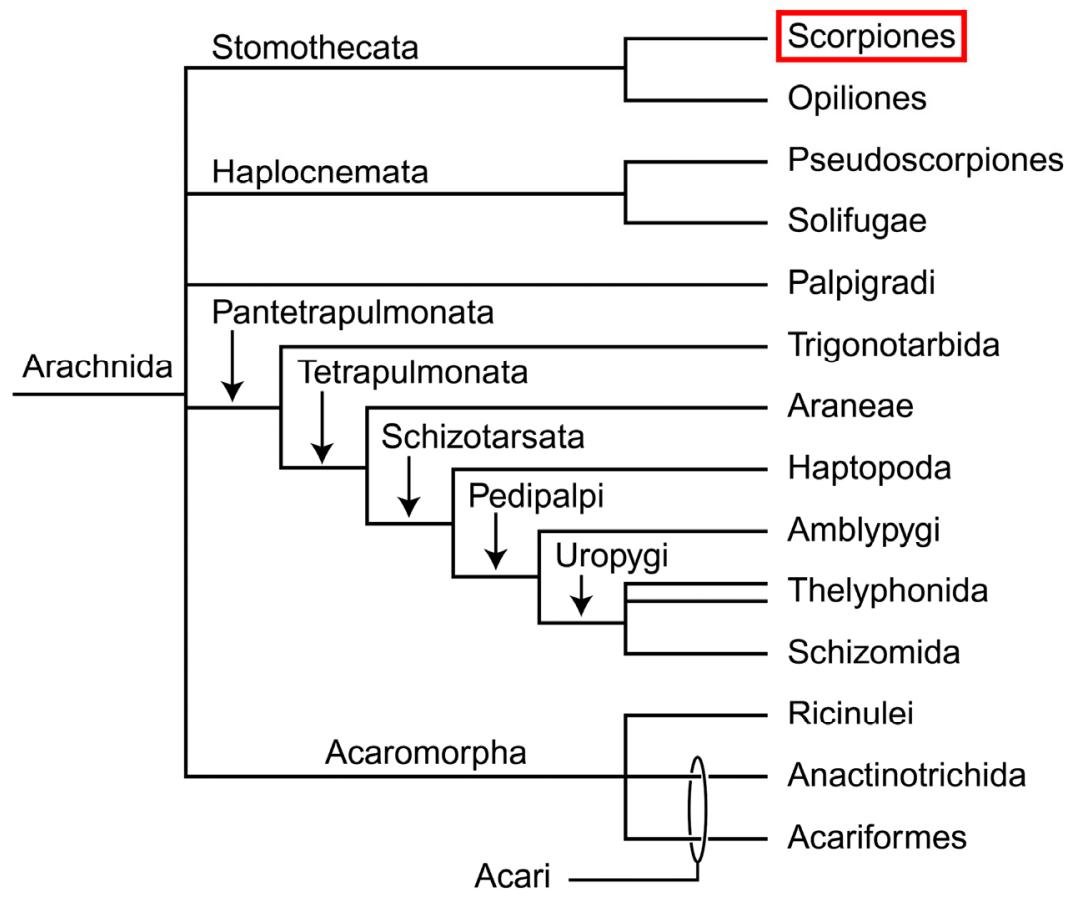

Scorpions are notorious for their deadly venoms. On the one hand, scorpion envenomation is a significant threat to public health in many regions around the world, which is a major cause of mortality in some underdeveloped countries in Latin America, South America, the Indian Subcontinent, the Middle East, and Africa. The number of worldwide scorpion stings is estimated to be around 1.2 million annually, resulting in more than 3,200 deaths [2]. On the other hand, scorpions developed their venom system as a primary weapon for capturing prey and defending against predators. Their venom systems contain the large families of toxins with a broad biodiversity [3].

Studies on the systematical classification of scorpion species from around the world and from specific countries have recently been garnering a great deal of attention [4-8]. Scorpion toxins have also attracted the fervent attention of a considerable number of researchers, due to the potential for developing therapeutic drugs [9-11]. In this review, we present the scorpion fauna of China. Additionally, scorpion toxins or genes from China are listed systematically. Using scorpion species and their toxins from China as an example, we try to build the bridge between scorpion species and their toxins, which helps us to not only understand the relationship of scorpion species and their toxins, but also show insights into the dynamic and functional evolution of the scorpion venom arsenal.

\section{Scorpion Species from China}

Chinese scorpion taxonomy research was started by the visiting scientists, dating back to 1879 with the first description of a Chinese scorpion (Buthus martensii Karsch also means Mesobuthus martensii Karsch, see the review [12]). There were 19 species and subspecies reported before 2003 [12], covering 
five families and nine genera. Since then, some Chinese researchers began to study scorpion classification and identification in China, particularly two representative groups: Minsheng Zhu team from Hebei University and our group. Qi et al. published the first comprehensive report on scorpions from Xizang, and discovered eight new species belonging to the families Chaerilidae (Chaerilus) and Euscorpiidae (Euscorpiops and Scorpiops) [13]. Subsequently, new genera, new species, a new record of genera and species, and re-descriptions were reported continuously [14-37]. At the same time, some revisions on scorpion distribution and taxonomy of the genera were completed [16,20,29,30,33-36]. A recent report began to focus on the impact of climate and environmental changes on the evolution and formation of scorpion species from China [38].

Currently, 53 species of 12 genera of five families (Buthidae, Chaerilidae, Euscorpiidae, Hemiscorpiidae and Scorpionidae) are recorded in China: (Table 1). Buthidae (Buthidae C. L. Koch, 1837) is the most widely distributed family in China, including six genera (Hottentotta with two species, Isometrus with three species, Lychas with two species, Mesobuthus with nine species, Orthochirus with one species, and Razianus with one species) and 18 species and subspecies (Table 1). They are distributed across most provinces except for Guangdong, Guizhou, Heilongjiang, Hunan, Jiangsu, Jilin, and Sichuan. Chaerilidae (Chaerilidae Pocock, 1893) has just a monotype genus Chaerilus, and all eight of the chaerilid species are found in South Xizang. Euscorpiidae (Euscorpiidae Laurie, 1896) is the largest family in China and has two genera Euscorpiops (11) and Scorpiops (11) mainly found in Yunnan and Xizang. Di et al. reported the Scorpiops species distributed in Central China [36], which is the first record of the family Euscorpiidae (Arachnida: Scorpiones) from Central China [36]. Hemiscorpiidae (Hemiscorpiidae Pocock, 1893) has two genera (Liocheles with one species and Tibetiomachus with one species) from China. Liocheles species is found on Hainan island. Lourenço and Qi described one new genus (Tibetiomachus Lourenço and Qi, 2006 (Hemiscorpiidae)) and new species (Tibetiomachus himalayensis Lourenço and Qi, 2006) based on specimens from Xizang [23]. T. himalayensis is the first liochelid scorpion found in the high Himalayan Mountains of Xizang, and also the first example of the family to be collected out of its typical tropical and subtropical areas of distribution [23]. Scorpionidae (Scorpionidae Latreille, 1802) has one genus (Heterometrus) and three species reported in China: $H$. tibetanus found in Xizang but the other two species (H. longimanus and H. petersii) without an exact distribution area.

Table 1. Catalog of scorpion species from China.

\begin{tabular}{|l|l|l|l|c|}
\hline Family & Genera & \multicolumn{1}{|c|}{ Species (endemic) } & Distribution & References \\
\hline \multirow{5}{*}{ Buthidae } & \multirow{5}{*}{ Hottentotta } & $\begin{array}{l}\text { Hottentotta alticola } \\
\text { (Pocock, 1895) }\end{array}$ & \ 1 & {$[12]$} \\
\cline { 3 - 5 } & $\begin{array}{l}\text { Hottentotta songi } \\
\text { (Lourenço, Qi and Zhu, 2005) }\end{array}$ & Xizang (endemic) & {$[17,24]$} \\
\cline { 2 - 5 } & \multirow{5}{*}{ Isometrus } & $\begin{array}{l}\text { Isometrus maculatus } \\
\text { (DeGeer, 1778) }\end{array}$ & Hainan and Taiwan & {$[12,30]$} \\
\cline { 3 - 5 } & $\begin{array}{l}\text { Isometrus hainanensis Lourenço, } \\
\text { Qi and Zhu, 2005 }\end{array}$ & Hainan (endemic) & {$[12,30]$} \\
\cline { 3 - 5 } & $\begin{array}{l}\text { Isometrus tibetanus } \\
\text { Zhu and Lourenço, 2008 }\end{array}$ & Xizang (endemic) & {$[37]$} \\
\hline
\end{tabular}


Table 1. Cont.

\begin{tabular}{|c|c|c|c|c|}
\hline Family & Genera & Species (endemic) & Distribution & References \\
\hline & Lychas & $\begin{array}{l}\text { Lychas mucronatus } \\
\text { (Fabricius, 1798) }\end{array}$ & Guangxi, Hainan and Yunnan & [30] \\
\hline & & Lychas scutilus C. L. Koch, 1845 & Shanghai & [12] \\
\hline \multirow{11}{*}{ Buthidae } & \multirow{9}{*}{ Mesobuthus } & $\begin{array}{l}\text { Mesobuthus bolensis Sun, } \\
\text { Zhu and Lourenço, } 2010\end{array}$ & Xinjiang (endemic) & [17] \\
\hline & & $\begin{array}{l}\text { Mesobuthus caucasicus } \\
\text { intermedius (Birula, 1897) }\end{array}$ & Xinjiang & [12] \\
\hline & & $\begin{array}{l}\text { Mesobuthus caucasicus } \\
\text { przewalskii (Birula, 1897) }\end{array}$ & Xinjiang & [12] \\
\hline & & $\begin{array}{l}\text { Mesobuthus eupeus mongolcus } \\
\text { (Birula, 1911) }\end{array}$ & $\begin{array}{l}\text { Gansu, Inner Mongolia } \\
\text { (Neimenggu) and Ningxia }\end{array}$ & [20] \\
\hline & & $\begin{array}{l}\text { Mesobuthus eupeus thersites } \\
\text { (C. L. Koch, 1839) }\end{array}$ & Xinjiang & [20] \\
\hline & & $\begin{array}{l}\text { Mesobuthus karshius } \\
\text { Sun and Sun, } 2011 \\
\end{array}$ & Xinjiang (endemic) & [20] \\
\hline & & $\begin{array}{l}\text { Mesobuthus longichelus } \\
\text { Sun and Zhu, } 2010\end{array}$ & Xinjiang (endemic) & [19] \\
\hline & & $\begin{array}{l}\text { Mesobuthus martensii martensii } \\
\text { (Karsch, 1879) }\end{array}$ & $\begin{array}{l}\text { the south side of } 43^{\circ} \mathrm{N} \text { and the } \\
\text { north side of the Yangtze River, } \\
\text { bordered by the Helan } \\
\text { Mountains and the Tengger and } \\
\text { Mo Us sand desert in the west } \\
\text { and limited by the sea in the east }\end{array}$ & [39] \\
\hline & & $\begin{array}{l}\text { Mesobuthus martensii } \\
\text { hainanensis (Birula, 1904) }\end{array}$ & Hainan (endemic) & [12] \\
\hline & Orthochirus & $\begin{array}{l}\text { Orthochirus scrobiculosus } \\
\text { (Grube, 1873) }\end{array}$ & Northwest & [40] \\
\hline & Razianus & $\begin{array}{l}\text { Razianus xinjianganus Lourenço, } \\
\text { Sun and Zhu, } 2010\end{array}$ & Xinjiang (endemic) & [25] \\
\hline \multirow{8}{*}{ Chaerilidae } & \multirow{8}{*}{ Chaerilus } & $\begin{array}{l}\text { Chaerilus conchiformus Zhu, } \\
\text { Han \& Lourenço, } 2008\end{array}$ & Xizang (endemic) & [16] \\
\hline & & $\begin{array}{l}\text { Chaerilus dibangvalleycus } \\
\text { Bastawade, } 2006\end{array}$ & Xizang (endemic) & [34] \\
\hline & & $\begin{array}{l}\text { Chaerilus mainlingensis } \\
\text { Di and Zhu, } 2009\end{array}$ & Xizang (endemic) & [28] \\
\hline & & Chaerilus pictus (Pocock, 1890) & Xizang & [12] \\
\hline & & $\begin{array}{l}\text { Chaerilus tessellatus } \\
\text { Qi, Zhu and Lourenço, } 2005\end{array}$ & Xizang (endemic) & {$[13,34]$} \\
\hline & & $\begin{array}{l}\text { Chaerilus tricostatus } \\
\text { Pocock, } 1899\end{array}$ & Xizang & [34] \\
\hline & & Chaerilus tryznai Kovařík, 2000 & Xizang (endemic) & [34] \\
\hline & & $\begin{array}{l}\text { Chaerilus wrzecionkoi } \\
\text { Kovařík, } 2012\end{array}$ & Xizang (endemic) & [26] \\
\hline \multirow{2}{*}{ Euscorpiidae } & \multirow{2}{*}{ Euscorpiops } & $\begin{array}{l}\text { Euscorpiops asthenurus } \\
\text { (Pocock, 1900) }\end{array}$ & Xizang & [29] \\
\hline & & $\begin{array}{l}\text { Euscorpiops kamengensis } \\
\text { Bastawade, } 2006\end{array}$ & Xizang (endemic) & [29] \\
\hline
\end{tabular}


Table 1. Cont.

\begin{tabular}{|c|c|c|c|c|}
\hline Family & Genera & Species (endemic) & Distribution & References \\
\hline \multirow{20}{*}{ Chaerilidae } & \multirow{9}{*}{ Chaerilus } & $\begin{array}{l}\text { Euscorpiops karschi Qi, } \\
\text { Zhu and Lourenço, } 2005\end{array}$ & Xizang (endemic) & [29] \\
\hline & & Euscorpiops kubani Kovařík, 2004 & Yunnan & [35] \\
\hline & & Euscorpiops novaki Kovařík, 2005 & Xizang (endemic) & [29] \\
\hline & & $\begin{array}{l}\text { Euscorpiops puerensis } \mathrm{Di}, \\
\mathrm{Wu}, \mathrm{Cao}, \mathrm{Xiao} \text { and } \mathrm{Li}, 2010\end{array}$ & Yunnan (endemic) & {$[35]$} \\
\hline & & $\begin{array}{l}\text { Euscorpiops shidian } \\
\text { Qi, Zhu and Lourenço, } 2005\end{array}$ & Yunnan (endemic) & {$[35]$} \\
\hline & & $\begin{array}{l}\text { Euscorpiops vachoni } \\
\text { Qi, Zhu and Lourenço, } 2005\end{array}$ & Yunnan (endemic) & {$[35]$} \\
\hline & & $\begin{array}{l}\text { Euscorpiops validus } \\
\mathrm{Di}, \mathrm{Cao}, \mathrm{Wu} \text { and } \mathrm{Li}, 2010\end{array}$ & Yunnan (endemic) & {$[35]$} \\
\hline & & Euscorpiops xui Sun and Zhu, 2010 & Yunnan (endemic) & {$[35]$} \\
\hline & & $\begin{array}{l}\text { Euscorpiops yangi Zhu, } \\
\text { Zhang and Lourenço, } 2007\end{array}$ & Yunnan (endemic) & {$[35]$} \\
\hline & \multirow{11}{*}{ Scorpiops } & $\begin{array}{l}\text { Scorpiops atomatus Qi, } \\
\text { Zhu and Lourenço, } 2005\end{array}$ & Xizang (endemic) & [36] \\
\hline & & $\begin{array}{l}\text { Scorpiops hardwickii } \\
\text { (Gervais, 1843) }\end{array}$ & Xizang & {$[12,36]$} \\
\hline & & Scorpiops jendeki Kovařík, 1994 & Yunnan (endemic) & {$[12,36]$} \\
\hline & & $\begin{array}{l}\text { Scorpiops langxian Qi, } \\
\text { Zhu and Lourenço, } 2005\end{array}$ & Xizang (endemic) & [36] \\
\hline & & Scorpiops leptochirus Pcock, 1893 & Xizang & {$[36]$} \\
\hline & & Scorpiops lhasa Di and Zhu, 2009 & Xizang (endemic) & {$[27,36]$} \\
\hline & & $\begin{array}{l}\text { Scorpiops luridus Qi, } \\
\text { Zhu and Lourenço, } 2005\end{array}$ & Xizang (endemic) & {$[13,36]$} \\
\hline & & $\begin{array}{l}\text { Scorpiops margerisonae } \\
\text { Kovařík, } 2000\end{array}$ & Xizang (endemic) & {$[12,36]$} \\
\hline & & Scorpiops petersii Pocock, 1893 & Xizang & {$[12,33]$} \\
\hline & & $\begin{array}{l}\text { Scorpiops pococki } \mathrm{Qi}, \\
\text { Zhu and Lourenço, } 2005\end{array}$ & Xizang (endemic) & {$[13,33]$} \\
\hline & & Scorpiops tibetanus Hirst, 1911 & Xizang (endemic) & {$[12,33]$} \\
\hline \multirow{2}{*}{ Hemiscorpiidae } & Liocheles & $\begin{array}{l}\text { Liocheles australasiae } \\
\text { (Fabricius, 1775) }\end{array}$ & Hainan & {$[12,30]$} \\
\hline & $\begin{array}{l}\text { Tibetiomachus } \\
\text { (endemic) }\end{array}$ & $\begin{array}{l}\text { Tibetiomachus himalayensis } \\
\text { Lourenço and Qi, } 2006\end{array}$ & Xizang (endemic) & [23] \\
\hline \multirow{3}{*}{ Scorpionidae } & \multirow{3}{*}{ Heterometrus } & $\begin{array}{l}\text { Heterometrus longimanus } \\
\text { (Herbst, 1800) }\end{array}$ & $\Delta 2$ & {$[12]$} \\
\hline & & $\begin{array}{l}\text { Heterometrus tibetanus Lourenço, } \\
\text { Qi and Zhu, } 2005\end{array}$ & Xizang (endemic) & [24] \\
\hline & & $\begin{array}{l}\text { Heterometrus petersii } \\
\text { (Thorell, 1876) }\end{array}$ & $\Delta 3$ & [12] \\
\hline 5 & $12(1)$ & $53(33)$ & & \\
\hline
\end{tabular}

$\Delta$ 1-3: the localities of these species are indecisive. 


\section{Toxins from Chinese Scorpion Species}

Scorpion venom has a large variety of biologically active components, most of which are the toxic peptide/protein (usually called toxins) of 1,000-9,000 Da in size [41,42]. Previous research has shown that the venom of a scorpion species has hundreds of different toxins, highlighting the large diversity of toxins in scorpion venom. Whereas most scorpion toxins have similar structural and functional characteristics, the individual components are in low abundance in the venom. Thus, it was difficult for us to isolate and purify the different single fractions from scorpion venom by the classic biochemical methods and techniques. It was therefore necessary to develop new methods or techniques for finding news toxins in scorpion venom and revealing the molecular diversity of scorpion toxins. More recently, some research groups made full use of proteomic and transcriptomic approaches to profile the venom toxin composition, which indicated that the general compositions of scorpion venoms vary among different families, genera, species and individuals [43-46]. Especially transcriptome analysis is a powerful approach not only to identify putative venom components, but also to better understand the biology of the venom gland $[47,48]$, which was widely adopted by the research groups involving in scorpion venoms from the global world. There are several groups making use of such strategy and measure in this field, among which are the Lourival D Possani team from Mexico (National Autonomous University) and our team from China (Wuhan University) (Table 2).

Table 2. Summary of scorpion species with the venom transcriptomic or proteomic analysis from the world.

\begin{tabular}{|c|c|c|c|c|}
\hline Family & Species & $\begin{array}{c}\text { Transcriptomic } \\
\text { analysis }\end{array}$ & $\begin{array}{c}\text { Proteomic } \\
\text { analysis }\end{array}$ & References \\
\hline \multirow{11}{*}{ Buthidae } & Lychas mucronatus & + & & {$[48,73]$} \\
\hline & Isometrus maculates & & & {$[48]$} \\
\hline & Buthus martensii $(=$ M. martensii) & & + & [49] \\
\hline & Hottentotta judaicus & + & & {$[77]$} \\
\hline & Tityus discrepans & + & + & {$[43,78]$} \\
\hline & Tityus stigmurus & + & + & {$[79,80]$} \\
\hline & Tityus cambridgei & & + & {$[81]$} \\
\hline & Tityus costatus & & + & {$[82]$} \\
\hline & Tityus pachyurus & & + & {$[83]$} \\
\hline & Androctonus crassicauda & + & + & [84] \\
\hline & $\begin{array}{l}\text { Androctonus mauretanicus } \\
\text { mauretanicus }\end{array}$ & & + & [85] \\
\hline \multirow{4}{*}{ Scorpionidae } & Heterometrus petersii & + & + & {$[45]$} \\
\hline & Heterometrus longimanus & & + & {$[86]$} \\
\hline & Pandinus cavimanus & + & + & [87] \\
\hline & Urodacus yaschenkoi & + & + & [88] \\
\hline \multirow{2}{*}{ Euscorpiidae } & Scorpiops jendeki & + & & {$[72]$} \\
\hline & Scorpiops margerisonae & + & & {$[48]$} \\
\hline \multirow{2}{*}{$\begin{array}{l}\text { Hemiscorpiidae } \\
\text { (Liochelidae) }\end{array}$} & Liocheles australasiae & + & & [89] \\
\hline & Opisthacanthus cayaporum & + & + & {$[90,91]$} \\
\hline Caraboctonidae & Hadrurus gertschi & + & & {$[47]$} \\
\hline \multirow{2}{*}{ Chaerilidae } & Chaerilus tricostatus & + & & {$[75]$} \\
\hline & Chaerilus tryznai & + & & {$[75]$} \\
\hline
\end{tabular}


In the 1990s, our lab in China started to construct the first venomous gland cDNA library of the scorpion M. martensii [49]; M. martensii has been extensively studied due to its large biomass and its usage as raw material in traditional Chinese medicine for many centuries to treat various diseases such as apoplexy, epilepsy, rheumatoid arthritis, and chronic pain [50]. From the M. martensii library, a large number of putative toxins have been described, including NaTx (toxins specific for the sodium channels) [51-56], KTx (toxins specific for the potassium channels) [57-63], ClTx (toxins specific for chloride channels) [64], CaTx (toxins for ryanodine receptors) [65], Bpp-like (bradykinin-potentiating peptide-like) peptide [66], cytolytic peptide [67,68], and other functional peptides [69-71]. In 2009, Ma et al. conducted a transcriptomic analysis of the venom gland of Scorpiops jendeki [72], which is classified to be one member of the family Euscorpiidae and whose venom has never before been investigated. This work revealed that the venom of the scorpion $S$. jendeki has at least 10 known toxin types ( $\alpha$-KTx ( $\alpha$ subfamily of toxin specific for the potassium channel), scorpine-like peptide, calcine (toxin specific for ryanodine receptor), cytolytic peptide, TIL (trypsin-inhibitor-like) peptide, lysozyme, La1-like peptide, opistoporin-like peptide, anionic peptide, and SPSV (serine protease from scorpion venom)) and nine atypical types of peptide/protein [72]. In 2010, the toxin components from the venom of the scorpion $H$. petersii were evaluated by both transcriptomic and proteomic analyses [45], which resulted in the discovery of 10 known and 12 atypical types of venom peptide/protein from this scorpion venom. The 10 known types of venom peptide/protein include two types of potassium channel toxins

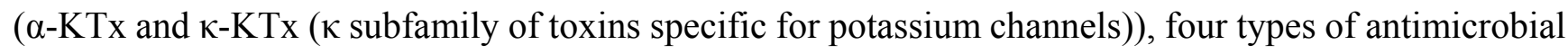
and cytolytic peptides (scorpine-like peptides, cytolytic peptide, opistoporin-like peptide and Pin2-like peptide), and one type for each of calcine, La1-like peptide, phospholipase A2, and SPSV. The 12 atypical families are composed of acid phosphatase, diuretic peptide and ten orphan families. During the same year, our group provided a comparative analysis of the venom transcriptome of the scorpion Lychas mucronatus from different geographical regions in China: one region is Hainan province and the other is Yunnan province [73]. Interestingly, this work identified a large number of new venom molecules, and also revealed the fact that the venom peptide/protein of the same scorpion species from different geographical regions is highly diversified. Intraspecies variation of venom composition has been more recently confirmed for the case of Tityus serrulatus [74]. In 2012, our lab studied the venom gland transcriptome analyses of three scorpion species: two Buthidae species (L. mucronatus and Isometrus maculatus) and one Euscorpiidae species (Scorpiops margerisonae) [48]. Transcriptomic analysis of these three scorpion species venom glands revealed 14 known types of venom peptide/protein, covering NaTx, $\alpha$-KTx, $\beta$-KTx ( $\beta$ subfamily of toxin specific for potassium channel) and scorpine-like peptide, calcine, LVP (lipolysis-activating peptide), BPP-like (bradykinin-potentiating peptide-like), BmKb1-like peptide, cytolytic peptide, pandinin-1-like peptide, pandinin-2-like peptide, anionic peptide, La1-like peptide and SPSV. Comparative transcriptome and molecular phylogenetic analyses elucidated that six types of venom peptide/protein, that is to say " $\alpha-\mathrm{KTx}, \beta-\mathrm{KTx}$, scorpine-like peptide, anionic peptide, Lal-like peptide, and SPSV," were likely recruited into the scorpion venom peptidome/protome before the lineage split between Euscorpiidae and Buthidae. After that, these recruited genes underwent individual or multiple gene duplication events, followed by gene mutations, which significantly enriched the molecular diversity of scorpion venom peptide/protein. Recently, He et al. performed a transcriptomic analysis of the venom glands from two scorpion species of the family Chaerilidae, Chaerilus tricostatus and Chaerilus tryznai [75]. Fourteen types of venom peptide/protein 
and 74 atypical venom molecules were discovered in two species. Surprisingly, the venom components of the family Chaerilidae were also found to have four toxin types (NaTx, $\beta-\mathrm{KTx}$, Scamp (short cationic antimicrobial peptide) and BPP-like), which were previously considered to be specific to the family Buthidae. Moreover, the cytolytic peptide was the most abundant toxin type in the venom of the family Chaerilidae, sharing the same expression pattern in the family Euscorpiidae. Lastly, three toxin types of NaTx, $\beta$-KTx and BPP-like were recruited into the venom before the lineage split between Buthidae and non-Buthidae families by comparative transcriptome and molecular phylogenetic analyses. This paper made a clear fact that the family Chaerilidae has a unique venom arsenal that is different from either the family Buthidae or the other non-Buthidae families, which depicts the evolutionary trace of scorpion venom peptide/protein components from Buthidae to non-Buthidae. More recently, our lab decoded the draft genome sequence of the scorpion M. martensii, and found 116 genes encoding venom neurotoxins located in the M. martensii genome, including $61 \mathrm{NaTx}$ (toxins for sodium channels), $46 \mathrm{KTx}$ (toxins for potassium channels), five CITx (toxins for chloride channels) and four CaTx (toxins for ryanodine receptors) genes [76] et al. In total, our group had constructed nine venom gland cDNA libraries covering eight scorpion species from China, and then performed their transcriptome analyses (Table 2). The work allows the characterization of a large family of venom molecules, belonging to either known or unknown scorpion venom peptide/proteins, which not only supplies solid clues for understanding the molecular diversity of scorpion venom peptide/protein, but also provides new sets of venom molecules with therapeutic potential. Forthermore, the work contributes to a majority of new toxin molecules from Chinese scorpion species, and shows insights into the evolution of the scorpion venom arsenal by comparison with venom data from other scorpion lineages, as well as helps us to understand the dynamic and functional evolution of scorpion species and their toxins (Figure 2).

Figure 2. Recruitment patterns of toxin types into the scorpion venom arsenal $[48,75]$.

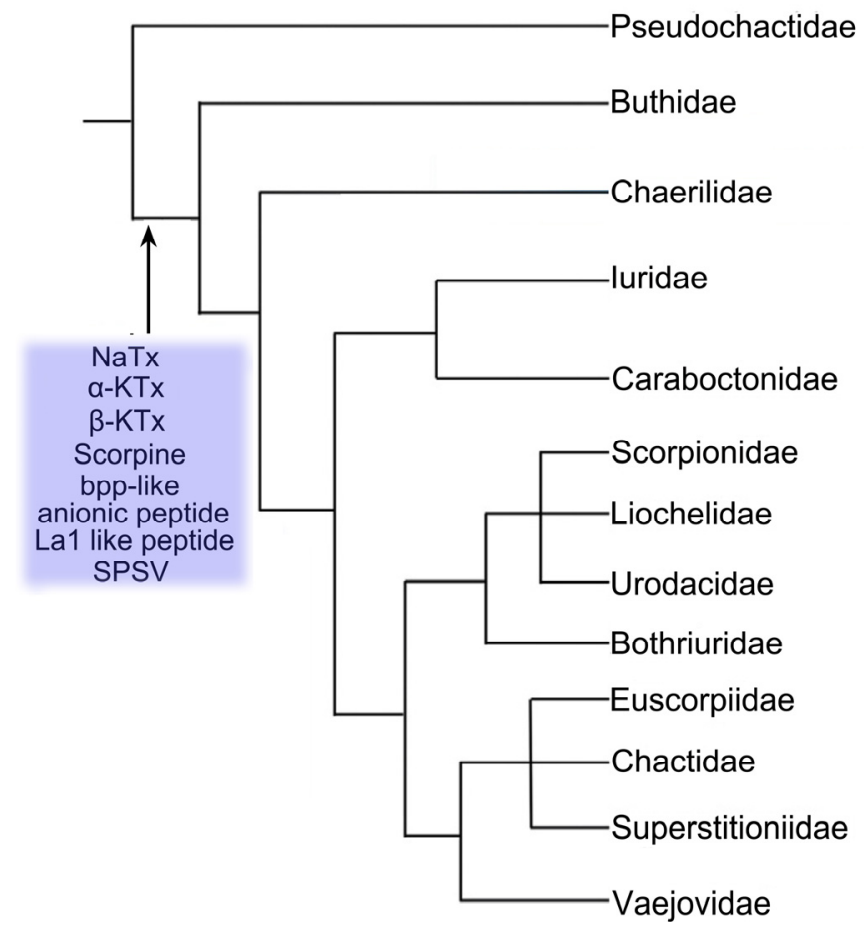




\section{Diverse Functions of Toxins from Chinese Scorpion Species}

\section{1. $\mathrm{Na}^{+}$Channel Modulators}

The NaTxs are a kind of toxin with 58-76 amino acid residues stabilized by four disulfide bonds, and they can modulate the inactivation and activation of the sodium channels by $\alpha$-NaTxs and $\beta$-NaTxs, respectively [92]. The isolation and function of the different NaTxs from the scorpion M. martensii were reviewed early in 2002 [50]. Since then, there was some progress in characterizing the functions of NaTxs in China. As for NaTxs from the scorpion M. martensii, the toxin BmKIM was found to be toxic to both mammal and insects, and inhibits the sodium currents in rat doesal root ganglion neurons and ventricular myocytes. It also could protect against the cardiac arrhythmia in the rat model of the aconitine-induced arrhythmia [56]. The effect of toxin BmKI on the sodium channel currents in dorsal root ganglion neurons was investigated, and it was found that the inhibitory effect of BmKI on open-state inactivation of tetrodotoxin-sensitive sodium currents was stronger than that of tetrodotoxin-resistant sodium currents [93]. Toxin BmK alphaIV was cloned and expressed, and pharmacological experiments indicated that it could increase the peak amplitude and prolonged the inactivation phase of rNav1.2 channel currents [94]. Recently, toxin BmoTX14 was found to selectively inhibit the fast inactivation of $\mathrm{mNa}(\mathrm{v}) 1.4\left(\mathrm{EC}_{50}=82.3 \pm 15.7 \mathrm{nM}\right)$ rather than that of $\mathrm{rNa}(\mathrm{v}) 1.2\left(\mathrm{EC}_{50}>30 \mu \mathrm{M}\right)$ [52]. Besides the scorpion $M$. martensii, the NaTxs from the $M$. eupeus were also studied. The two-electrode voltage-clamp recordings toxins revealed that toxin MeuNaTx $\alpha-1,-2,-4$, and -5 slowed inactivation of $\mathrm{DmNa}(\mathrm{v}) 1$ and were inactive on Nav1.8 at micromolar concentrations. Among other six Nav1.2 Nav1.7 channels, these toxins exhibited differential specificity [95]. In addition, few $\beta$-NaTxs from Chinse scorpions was characterized in past years, which will be an interesting suject in the future. In summary, the work further hightlights the functional diversity of the NaTxs from different scorpion species.

\section{2. $K^{+}$Channel Blockers}

The KTxs are usually blockers of different types of the potassium channels, and their molecular diversity was recently reviewed in the 2008 [96]. In past years, many KTxs from the scorpion M. martensii and M. eupeus were found to block different potassium channels [41,97,98]. However, remarkable advances were achieved in the scorpion toxin-potassium channel interactions at the structural level. Through combining the mutagenesis experiments and computational modeling, the different toxin-potassium channel-binding modes and their interaction details were characterized, such as BeKm-1 acting on the hERG channel [99], maurotoxin acting on Kv1.2 channel [100], charybdotoxin acting on BKCa channel in the presence and absence of $\beta 4$ subunits [101,102], Kunitz-type toxins acting on Kv1.3 channel [103], BmP05 acting on SKCa3 channel [10]. Based on these toxin-potassium channel interactions, a novel control technique of toxin-potassium channel recognition was developed [104], and used to rationally design a selective ADWX-1 peptide for treating the Kv1.3 channel-mediated multiple sclerosis $[103,105,106]$. These progresses indicate the importance and prospects of the structural information on the scorpion toxin-potassium channel interactions. 


\subsection{Antimicrobial Peptides}

The scorpion only has an innate immune system that enables it to resist microbial infections, which suggests that there are a variety of antibacterial peptides in the body of scorpion. In 1993, a scorpion defensin with a $4 \mathrm{kDa}$ was purified and characterized from the scorpion Leiurus quinquestriatus [107]. Consequently, research interests mainly focused on the discovery of antibacterial peptides from scorpion venoms [108]. Since 2001, our group found a series of AMPs from the venoms of Chinese scorpion species, and identified their antibacterial functions and mechanisms [67,68,109-111].

A group of toxin precursors were characterized from the venom of the scorpion $M$. martensii, which were deduced to encode a novel venom peptide family: no disulfide bridge peptide (NDBP) with antimicrobial activity, such as $\mathrm{BmKn} 1$ and $\mathrm{BmKn} 2$. The synthetic $\mathrm{BmKn} 2$ was then confirmed to inhibit the growth of the standard bacteria [67]. Kn2-7 was derived from BmKn2 to show not only increased inhibitory activity against both standard bacteria and clinical antibiotic-resistant strains (such as methicillin-resistant Staphylococcus aureus: MRSA), but also reduced hemolytic activity. Moreover, Kn2-7 effectively protected the $S$. aureus mouse skin infection of mice. Kn2-7 exerted its bactericidal activity by binding to the lipoteichoic acid (LTA) in the $S$. aureus cell wall and the lipopolysaccharides (LPS) in the E. coli cell wall, respectively [111].

Mucroporin was the second representative of antimicrobial peptides from Chinese scorpion venoms [109]. Mucroporin was cloned and characterized from the venom of L. mucronatus. Mucroporin specifically inhibited the growth of Gram-positive bacteria. Subsequently, Mucroporin-M1 was designed from the molecular template of Mucroporin. Mucroporin-M1 not only had the higher antibacterial activity against both standard and clinic Gram-positive bacteria, but also displayed wider antibacterial spectra (effect on Gram-negative bacteria).

Finally, Ctriporin was a new anti-methicillin-resistant $S$. aureus peptide from the venom of the scorpion C. tricostatus [112]. The MICs of Ctriporin against standard and clinical antibiotic-resistant Gram-positive bacterial strains were 5 to $20 \mu \mathrm{g} / \mathrm{mL}$. Furthermore, external use of the peptide Ctriporin dramatically decreased the bacterial counts and cured skin infections in mice. Ctriporin was demonstrated to have antimicrobial activity via the bactericidal mechanism of rapid cell lysis.

Combined, the other antimicrobial peptides from Chinese scorpion venoms were screened and identified by our group [113,114], and these works confirm that scorpion venom is a rich resource of AMPs, which opens a new window for discovering antimicrobial resources and agents, and sheds some light into developing antimicrobial drugs against multidrug-resistant pathogens that seriously threaten human health.

\subsection{Protease Inhibitors}

It is well known that scorpion venom contains a variety of peptides and proteins used as a molecular arsenal for predation and defense. Naturally, it is interesting how scorpions protect their venom peptides/proteins from degradation. Under the natural selection pressure, scorpions strive to construct more efficient toxic peptides/proteins by recruitment events so as to be evolutionarily successful $[48,75]$. Peptide protease inhibitors are also considered to be the earliest venom peptide/protein type recruited from the other body proteins, accompanied by the recruitment of peptide toxins. 
Several protease inhibitors have been isolated from scorpion venom. First, a new Kunitz-type venom peptide gene precursor, SdPI, was cloned and characterized from a venom gland cDNA library of the scorpion L. mucronatus [115]. It codes for a signal peptide of 21 residues and a mature peptide of 59 residues. The recombinant SdPI peptide showed trypsin inhibitory activity with high potency $\mathrm{Ki}=1.6 \times 10^{-7} \mathrm{M}$ and thermostability. SdPI is the first functionally characterized Kunitz-type trypsin inhibitor from scorpion venom, and it may represent a new class of Kunitz-type venom peptides. Second, one Ascaris-type protease inhibitor, SjAPI, was discovered from the venom of the scorpion S. jendeki [116]. SjAPI contains 64 residues with a classical Ascaris-type cysteine framework reticulated by five disulfide bridges, but is different from all known protease inhibitors from venomous animals. SjAPI has $\alpha$-chymotrypsin- and elastase-inhibiting properties. SjAPI is the first functionally characterized animal toxin peptide with an Ascaris-type fold. Third, a Kunitz-type protease inhibitor (BmKPI) was characterized from the venom gland of the scorpion M. martensii [117]. BmKPI showed strong and wide inhibitory activity toward trypsin $\left(\mathrm{Ki} 1.8 \times 10^{-6} \mathrm{M}\right)$, chymotrypsin $\left(\mathrm{Ki} 3.2 \times 10^{-8} \mathrm{M}\right)$, and elastase (Ki $\left.1.6 \times 10^{-7} \mathrm{M}\right)$. Cysteine mutagenesis indicated that the disulfide bridge Cys53-Cys61 has little effect on its inhibitory activity against elastase. Therefore, BmKPI is a new multifunctional serine protease inhibitor and is also the first functionally characterized Kunitz-type elastase inhibitor from scorpion venoms.

Proteases catalyze the breakdown of proteins, which is a normal process necessary to maintain cellular homeostasis. Both proteases and protease inhibitors are employed for medicinal and pharmaceutical purposes [118]. For example, trypsin is involved in many inflammatory reactions in the human body, such as pancreatitis and cardiovascular or nervous systems diseases [119,120]. Thus, trypsin inhibitors, such as ulinastatin and aprotinin, are used as an anti-inflammatory therapy in clinic. There is no doubt that this work suggests the fact that scorpion venom is a rich source of protease peptide inhibitors with a great deal of potential for therapeutic drugs.

\section{Conclusions}

The scorpion is one of the important arachnids in the phylum Arthropoda. It has unique features, such as poisonous venom, fluorescence and so on, which increasingly attract the attention and interest of scientists around the world. Recently, some work has expanded the understanding of the biological functions of scorpion toxins, such as the discovery of enzyme inhibitors in scorpion venoms. Using scorpion species and their toxins from China as an example, we try to build the bridge between scorpion species and their toxins, in order to help us understand the molecular and functional diversity of the scorpion venom arsenal, the dynamic and functional evolution of scorpion toxins, and the relationship of scorpion species and their toxins.

\section{Funding}

This work was supported by grants from the National Basic Research Program of China (2010CB529800) and National Natural Sciences Foundation of China (number 31071942) and the Basic Project of Ministry of Science and Technology of China (No. 2007FY210800). 


\section{Conflicts of Interest}

The authors declare no conflict of interest.

\section{References}

1. Shultz, J.W. A phylogenetic analysis of the arachnid orders based on morphological characters. Zool. J. Linn. Soc. 2007, 150, 221-265.

2. Chippaux, J.P.; Goyffon, M. Epidemiology of scorpionism: A global appraisal. Acta Trop. 2008, 107, 71-79.

3. Rodriguez de la Vega, R.C.; Schwartz, E.F.; Possani, L.D. Mining on scorpion venom biodiversity. Toxicon 2010, 56, 1155-1161.

4. Lourenço, W.R.; Pham, D.S. First record of a cave species of Euscorpiops Vachon from Viet Nam (Scorpiones, Euscorpiidae, Scorpiopinae). C. R. Biol. 2013, 336, 370-374.

5. Miller, A.L.; Makowsky, R.A.; Formanowicz, D.R.; Prendini, L.; Cox, C.L. Cryptic genetic diversity and complex phylogeography of the boreal North American scorpion, Paruroctonus boreus (Vaejovidae). Mol. Phylogenet. Evol. Mol. Phylogenet. Evol. 2014, 71, 298-307.

6. Graham, M.R.; Jaeger, J.R.; Prendini, L.; Riddle, B.R. Phylogeography of Beck's Desert Scorpion, Paruroctonus becki, reveals Pliocene diversification in the Eastern California Shear Zone and postglacial expansion in the Great Basin Desert. Mol. Phylogenet. Evol. 2013, 69, 502-513.

7. Soleglad, M.E.; Fet, V. Further observations on scorpion genera Hadrurus and Hoffmannihadrurus (Scorpiones, Caraboctonidae). Zookeys 2010, 59, 1-14.

8. Lourenço, W.R.; Ythier, E. The remarkable scorpion diversity in the Ecuadorian Andes and description of a new species of Tityus C. L. Koch, 1836 (Scorpiones, Buthidae). Zookeys 2013, $307,1-13$.

9. Smith, J.J.; Vetter, I.; Lewis, R.J.; Peigneur, S.; Tytgat, J.; Lam, A.; Gallant, E.M.; Beard, N.A.; Alewood, P.F.; Dulhunty, A.F. Multiple actions of phi-LITX-Lw1a on ryanodine receptors reveal a functional link between scorpion DDH and ICK toxins. Proc. Natl. Acad. Sci. USA 2013, 110, 8906-8911.

10. Feng, J.; Hu, Y.T.; Yi, H.; Yin, S.J.; Han, S.; Hu, J.; Chen, Z.Y.; Yang, W.S.; Cao, Z.J.; de Waard, M.; et al. Two conserved arginine residues from the SK3 potassium channel outer vestibule control selectivity of recognition by scorpion toxins. J. Biol. Chem. 2013, 288, 12544-12553.

11. Mamelak, A.N.; Rosenfeld, S.; Bucholz, R.; Raubitschek, A.; Nabors, L.B.; Fiveash, J.B.; Shen, S.; Khazaeli, M.B.; Colcher, D.; Liu, A.; et al. Phase I single-dose study of intracavitary-administered iodine-131-TM-601 in adults with recurrent high-grade glioma. J. Clin. Oncol. 2006, 24, 3644-3650.

12. Zhu, M.S.; Qi, J.X.; Song, D.X. A checklist of scorpions from China (Arachnida: Scorpiones). Acta Arachnol. Sin. 2004, 13, 111-118. 
13. Qi, J.X.; Zhu, M.S.; Lourenço, W.R. Eight new species of the genera Scorpiops Peters, Euscorpiops Vachon, and Chaerilus Simon (Scorpiones: Euscorpiidae, Chaerilidae) from Tibet and Yunnan, China. Euscorpius 2005, 32, 1-40.

14. Di, Z.Y.; Zhu, M.S. Redescription of Scorpiops margerisonae Kovařík, 2000, with the first record of its female, from China (Scorpiones: Euscorpiidae: Scorpiopinae). Euscorpius 2010, 104, 1-9.

15. Zhu, M.S.; Zhang, L.; Lourenço, W.R. One new species of scorpion belonging to the genus Euscorpiops Vachon, 1980 from South China (Scorpiones: Euscorpiidae, Scorpiopinae). Zootaxa 2007, 1582, 19-25.

16. Zhu, M.S.; Han, G.X.; Lourenço, W.R. The chaerilid scorpions of China (Scorpiones: Chaerilidae). Zootaxa 2008, 1943, 37-52.

17. Sun, D.; Zhu, M.S.; Lourenço, W.R. A new species of Mesobuthus (Scorpiones: Buthidae) from Xinjiang, China, with notes on Mesobuthus songi. J. Arachnol. 2010, 38, 35-43.

18. Sun, D.; Zhu, M.S. One new species of scorpion belonging to the genus Euscorpiops Vachon, 1980 from Yunnan, China (Scorpiones: Euscorpiidae, Scorpiopinae). Zootaxa 2010, 2399, 61-68.

19. Sun, D.; Zhu, M.S. A new species of the genus Mesobuthus Vachon, 1950 (Scorpiones, Buthidae) from Xinjiang, China. ZooKeys 2010, 37, 1-12.

20. Sun, D.; Sun, Z.N. Notes on the genus Mesobuthus (Scorpiones: Buthidae) in China, with description of a new species. J. Arachnol. 2011, 39, 59-75.

21. Qi, J.X.; Zhu, M.S.; Lourenço, W.R. Redescription of Mesobuthus martensii martensii (Karsch, 1879)(Scorpiones: Buthidae) from China. Revista ibérica de Aracnol. 2004, 10, 137-144.

22. Lourenço, W.R.; Qi, J.X.; Zhu, M.S. Description of a new species of Isometrus Ehrenberg 1828 (Scorpiones, Buthidae) from the Island of Hainan. China. Boletín SEA 2005, 36, 57-63.

23. Lourenço, W.R.; Qi, J.X. Mountain scorpions: A new genus and species from Tibet (China). Comptes Rendus Biol. 2006, 329, 289-295.

24. Lourenço, W.R.; Qi, J.X.; Zhu, M.S. Description of two new species of scorpions from China (Tibet) belonging to the genera Mesobuthus Vachon (Buthidae) and Heterometrus Ehrenberg (Scorpionidae). Zootaxa 2005, 985, 1-16.

25. Lourenço, W.R.; Sun, D.; Zhu, M.S. Razianus xinjianganus sp. nov.: A New Record Genus and New Species of (Scorpiones, Buthidae) from China. J. Hebei Univ. (Nat. Sci. Ed.) 2010, 30, 307-312.

26. Kovařík, F. Five new species of Chaerilus Simon, 1877 from China, Indonesia, Malaysia, Philippines, Thailand, and Vietnam (Scorpiones: Chaerilidae). Euscorpius 2012, 149, 1-14.

27. Di, Z.Y; Zhu, M.S. One new species of the Genus Scorpiops Peters, 1861 (Scorpiones: Euscorpiidae, Scorpiopinae) from Xizang, China. Zootaxa 2009, 2030, 39-48.

28. Di, Z.Y.; Zhu, M.S. A new species of Chaerilus Simon, 1877 (Scorpiones, Chaerilidae) from China. Acta Arachnol. 2009, 58, 97-102.

29. Di, Z.Y.; Wu, Y.L.; Cao, Z.J.; Xiao, H.; Li, W.X. A catalogue of the genus Euscorpiops Vachon, 1980 (Scorpiones: Euscorpiidae, Scorpiopinae) from China, with description of a new species. Zootaxa 2010, 2477, 49-61.

30. Di, Z.Y.; Cao, Z.J.; Wu, Y.L.; Zhu, L.; Liu, H.; Li, W.X. The scorpions of Hainan Island, China (Arachnida: Scorpiones). Euscorpius 2013, 153, 1-22.' 
31. Di, Z.Y.; Cao, Z.J.; Wu, Y.L.; Li, W.X. A new species of the genus Euscorpiops Vachon, 1980 (Scorpiones: Euscorpiidae, Scorpiopinae) from Yunnan, China. Zootaxa 2010, 2361, 13-22.

32. Di, Z.Y.; Zhu, M.S. The male of Euscorpiops karschi (Scorpiones: Euscorpiidae, Scorpiopinae) from China (Xizang). Arthr. Sel. 2009, 18, 9-16.

33. Di, Z.Y.; Xu, X.B.; Cao, Z.J.; Wu, Y.L.; Li, W.X. Notes on the scorpions (Arachnida, Scorpiones) from Xizang with the redescription of Scorpiops jendeki Kovařík, 2000 (Scorpiones, Euscorpiidae) from Yunnan (China). ZooKeys 2013, 301, 51-99.

34. Di, Z.Y.; Wu, Y.L.; Cao, Z.J.; Fan, L.Q.; Li, W.X. The genus Chaerilus Simon, 1877 (Scorpiones: Chaerilidae) in China, with a description of the female C. tricostatus Pocock, 1899. Arthr. Sel. 2009, 18, 131-138.

35. Di, Z.Y.; He, Y.W.; Wu, Y.L.; Cao, Z.J.; Liu, H.; Jiang, D.H.; Li, W.X. The scorpions of Yunnan (China): Updated identification key, new record and redescriptions of Euscorpiops kubani and E. shidian (Arachnida, Scorpiones). ZooKeys 2011, 82, 1-33.

36. Di, Z.Y.; He, Y.W.; Cao, Z.J.; Wu, Y.L.; Li, W.X. The first record of the family Euscorpiidae (Arachnida: Scorpiones) from Central China, with a key of Chinese species of the genus Scorpiops. Euscorpius 2011, 118, 1-9.

37. Lourenco, W.R.; Zhu, M.S. A new species of the genus Isometrus Ehrenberg 1828 from China (Scorpiones, Buthidae). Acta Zootaxon. Sin. 2008, 33, 264-271.

38. Shi, C.M.; Ji, Y.J.; Liu, L.; Wang, L.; Zhang, D.X. Impact of climate changes from Middle Miocene onwards on evolutionary diversification in Eurasia: Insights from the mesobuthid scorpions. Mol. Ecol. 2013, 22, 1700-1716.

39. Shi, C.M.; Huang, Z.S.; Wang, L.; He, L.J.; Hua, Y.P.; Leng, L.; Zhang, D.X. Geographical distribution of two species of Mesobuthus (Scorpiones, Buthidae) in China: Insights from systematic field surveys and predictive models. J. Arachnol. 2007, 35, 215-226.

40. Shi, C.M.; Zhang, D.X. A review of the systematic research on buthid scorpions (Scorpiones: Buthidae). Acta Zootaxon. Sin. 2005, 30, 470-477.

41. Zhu, S.Y.; Peigneur, S.; Gao, B.; Luo, L.; Jin, D.; Zhao, Y.; Tytgat, J. Molecular diversity and functional evolution of scorpion potassium channel toxins. Mol. Cell Proteom. 2011, 10, M110 002832.

42. Cao, Z.J.; Luo, F.; Wu, Y.L.; Mao, X.; Li, W.X. Genetic mechanisms of scorpion venom peptide diversification. Toxicon 2006, 47, 348-355.

43. Batista, C.V.; D’Suze, G.; Gomez-Lagunas, F.; Zamudio, F.Z.; Encarnacion, S.; Sevcik, C.; Possani, L.D. Proteomic analysis of Tityus discrepans scorpion venom and amino acid sequence of novel toxins. Proteomics 2006, 6, 3718-3727.

44. Abdel-Rahman, M.A.; Quintero-Hernandez, V.; Possani, L.D. Venom proteomic and venomous glands transcriptomic analysis of the Egyptian scorpion Scorpio maurus palmatus (Arachnida: Scorpionidae). Toxicon 2013, 74C, 193-207.

45. Ma, Y.B.; Zhao, Y.; Zhao, R.; Zhang, W.P.; He, Y.W.; Wu, Y.L.; Cao, Z.J.; Guo, L.; Li, W.X. Molecular diversity of toxic components from the scorpion Heterometrus petersii venom revealed by proteomic and transcriptome analysis. Proteomics 2010, 10, 2471-2485. 
46. Abdel-Rahman, M.A.; Omran, M.A.; Abdel-Nabi, I.M.; Ueda, H.; McVean, A. Intraspecific variation in the Egyptian scorpion Scorpio maurus palmatus venom collected from different biotopes. Toxicon 2009, 53, 349-359.

47. Schwartz, E.F.; Diego-Garcia, E.; Rodriguez de la Vega, R.C.; Possani, L.D. Transcriptome analysis of the venom gland of the Mexican scorpion Hadrurus gertschi (Arachnida: Scorpiones). BMC Genomics 2007, 8, 119.

48. Ma, Y.B.; He, Y.W.; Zhao, R.M.; Wu, Y.L.; Li, W.X.; Cao, Z.J. Extreme diversity of scorpion venom peptides and proteins revealed by transcriptomic analysis: Implication for proteome evolution of scorpion venom arsenal. J. Proteomics 2012, 75, 1563-1576.

49. Zhu, S.Y.; Li, W.X.; Zeng, X.C.; Jiang, D.H.; Mao, X.; Liu, H. Molecular cloning and sequencing of two 'short chain' and two 'long chain' $\mathrm{K}(+)$ channel-blocking peptides from the Chinese scorpion Buthus martensii Karsch. FEBS Lett. 1999, 457, 509-514.

50. Goudet, C.; Chi, C.W.; Tytgat, J. An overview of toxins and genes from the venom of the Asian scorpion Buthus martensi Karsch. Toxicon 2002, 40, 1239-1258.

51. Zeng, X.C.; Li, W.X.; Zhu, S.Y.; Peng, F.; Jiang, D.H.; Yang, F.H.; Wu, K.L. Cloning and characterization of the cDNA sequences of two venom peptides from Chinese scorpion Buthus martensii Karsch (BmK). Toxicon 2000, 38, 893-899.

52. Dai, H.; Yin, S.J.; Li, T.; Cao, Z.J.; Ji, Y.H.; Wu, Y.L.; Li, W.X. Recombinant expression, purification, and characterization of scorpion toxin BmalphaTX14. Protein Expr. Purif. 2012, 82, 325-331.

53. Wang, K.; Yin, S.J.; Lu, M.; Yi, H.; Dai, C.; Xu, X.J.; Cao, Z.J.; Wu, Y.L.; Li, W.X. Functional analysis of the alpha-neurotoxin, BmalphaTX14, derived from the Chinese scorpion, Buthus martensii Karsch. Biotechnol. Lett. 2006, 28, 1767-1672.

54. Zeng, X.C.; Li, W.X.; Zhu, S.Y.; Peng, F.; Zhu, Z.H.; Liu, H.; Mao, X. Molecular cloning and sequence analysis of cDNAs encoding a beta-toxin-like peptide and two MkTx I homologues from scorpion Buthus martensii Karsch. Toxicon 2001, 39, 225-232.

55. Zhu, S.Y.; Li, W.X.; Zeng, X.C.; Liu, H.; Jiang, D.H.; Mao, X. Nine novel precursors of Buthus martensii scorpion alpha-toxin homologues. Toxicon 2000, 38, 1653-1661.

56. Peng, F.; Zeng, X.C.; He, X.H.; Pu, J.; Li, W.X.; Zhu, Z.H.; Liu, H. Molecular cloning and functional expression of a gene encoding an antiarrhythmia peptide derived from the scorpion toxin. Eur. J. Biochem. 2002, 269, 4468-4475.

57. Zeng, X.C.; Zhu, Z.H.; Li, W.X.; Zhu, S.Y.; Peng, F.; Mao, X.; Liu, H. Molecular cloning and genomic organization of a $\mathrm{K}(+)$ channel toxin from the Chinese scorpion Buthus martensii Karsch. Toxicon 2001, 39, 407-410.

58. Zhu, S.Y.; Li, W.X.; Zeng, X.C. Precursor nucleotide sequence and genomic organization of BmTXKS1, a new scorpion toxin-like peptide from Buthus martensii Karsch. Toxicon 2001, 39, 1291-1296.

59. Zeng, X.C.; Peng, F.; Luo, F.; Zhu, S.Y.; Liu, H.; Li, W.X. Molecular cloning and characterization of four scorpion $\mathrm{K}(+)$-toxin-like peptides: A new subfamily of venom peptides (alpha-KTx14) and genomic analysis of a member. Biochimie 2001, 83, 883-889. 
60. Zhu, S.Y.; Li, W.X.; Cao, Z.J. A naturally occurring non-coding fusion transcript derived from scorpion venom gland: Implication for the regulation of scorpion toxin gene expression. FEBS Lett. 2001, 508, 241-244.

61. Sheng, J.Q.; Xu, X.L.; Cao, Z.J.; Liu, W.H.; Wu, Y.L.; Zhu, S.Y.; Zeng, X.C.; Jang, D.H.; Mao, X.; Liu, H.; et al. Molecular cloning, genomic organization and functional characterization of a new short-chain potassium channel toxin-like peptide BmTxKS4 from Buthus martensii Karsch(BmK). J. Biochem. Mol. Toxicol. 2004, 18, 187-195.

62. Zeng, X.; Luo, F.; Li, W.X. Molecular dissection of venom from Chinese scorpion Mesobuthus martensii: Identification and characterization of four novel disulfide-bridged venom peptides. Peptides 2006, 27, 1745-1754.

63. Mao, X.; Cao, Z.J.; Yin, S.J.; Ma, Y.B.; Wu, Y.L.; Li, W.X. Cloning and characterization of BmK86, a novel $\mathrm{K}+-$ channel blocker from scorpion venom. Biochem. Biophys. Res. Commun. 2007, 360, 728-734.

64. Zeng, X.C.; Li, W.X.; Zhu, S.Y.; Peng, F.; Zhu, Z.H.; Wu, K.L.; Yiang, F.H. Cloning and characterization of a cDNA sequence encoding the precursor of a chlorotoxin-like peptide from the Chinese scorpion Buthus martensii Karsch. Toxicon 2000, 38, 1009-1014.

65. Cao, Z.J.; Xie, Y.; Dai, C.; Zhu, S.Y.; Yin, S.J.; Wu, Y.L.; Li, W.X. Cloning and characterization of a novel calcium channel toxin-like gene BmCa1 from Chinese scorpion Mesobuthus martensii Karsch. Peptides 2006, 27, 1235-1240.

66. Zeng, X.C.; Li, W.X.; Peng, F.; Zhu, Z.H. Cloning and characterization of a novel cDNA sequence encoding the precursor of a novel venom peptide (BmKbpp) related to a bradykinin-potentiating peptide from Chinese scorpion Buthus martensii Karsch. IUBMB Life 2000, 49, 207-210.

67. Zeng, X.C.; Wang, S.X.; Zhu, Y.; Zhu, S.Y.; Li, W.X. Identification and functional characterization of novel scorpion venom peptides with no disulfide bridge from Buthus martensii Karsch. Peptides 2004, 25, 143-150.

68. Zeng, X.C.; Li, W.X.; Wang, S.X.; Zhu, S.Y.; Luo, F. Precursor of a novel scorpion venom peptide (BmKn1) with no disulfide bridge from Buthus martensii Karsch. IUBMB Life 2001, 51, 117-120.

69. Zeng, X.C.; Wang, S.X.; Li, W.X. Identification of BmKAPi, a novel type of scorpion venom peptide with peculiar disulfide bridge pattern from Buthus martensii Karsch. Toxicon 2002, 40, $1719-1722$.

70. Zhu, S.Y.; Li, W.X.; Jiang, D.H.; Zeng, X.C. Evidence for the existence of insect defensin-like peptide in scorpion venom. IUBMB Life 2000, 50, 57-61.

71. Zhu, S.Y.; Li, W.X. Precursors of three unique cysteine-rich peptides from the scorpion Buthus martensii Karsch. Comp. Biochem. Physiol. B Biochem. Mol. Biol. 2002, 131, 749-756.

72. Ma, Y.B.; Zhao, R.M.; He, Y.W.; Li, S.R.; Liu, J.; Wu, Y.L.; Cao, Z.J.; Li, W.X. Transcriptome analysis of the venom gland of the scorpion Scorpiops jendeki: Implication for the evolution of the scorpion venom arsenal. BMC Genomics 2009, 10, 290.

73. Zhao, R.M.; Ma, Y.B.; He, Y.W.; Di, Z.Y.; Wu, Y.L.; Cao, Z.J.; Li, W.X. Comparative venom gland transcriptome analysis of the scorpion Lychas mucronatus reveals intraspecific toxic gene diversity and new venomous components. BMC Genomics 2010, 11, 452. 
74. Oliveira, F.N.; Mortari, M.R.; Carneiro, F.P.; Guerrero-Vargas, J.A.; Santos, D.M.; Pimenta, A.M.; Schwartz, E.F. Another record of significant regional variation in toxicity of Tityus serrulatus venom in Brazil: A step towards understanding the possible role of sodium channel modulators. Toxicon 2013, 73, 33-46.

75. He, Y.W.; Zhao, R.M.; di, Z.Y.; Li, Z.J.; Xu, X.B.; Hong, W.; Wu, Y.L.; Zhao, H.B.; Li, W.X.; Cao, Z.J. Molecular diversity of Chaerilidae venom peptides reveals the dynamic evolution of scorpion venom components from Buthidae to non-Buthidae. J. Proteomics 2013, 89, 1-14.

76. Cao, Z.J.; Yu, Y.; Wu, Y.L.; Hao, P.; Di, Z.Y.; He, Y.W.; Chen, Z.Y.; Yang, W.S.; Shen, Z.Y.; He, X.H.; et al. The genome of Mesobuthus martensii reveals a unique adaptation model of arthropods. Nat Commun. 2013, 4, 2602.

77. Morgenstern, D.; Rohde, B.H.; King, G.F.; Tal, T.; Sher, D.; Zlotkin, E. The tale of a resting gland: Transcriptome of a replete venom gland from the scorpion Hottentotta judaicus. Toxicon 2011, 57, 695-703.

78. D’Suze, G.; Schwartz, E.F.; Garcia-Gomez, B.I.; Sevcik, C.; Possani, L.D. Molecular cloning and nucleotide sequence analysis of genes from a cDNA library of the scorpion Tityus discrepans. Biochimie 2009, 91, 1010-1019.

79. Almeida, D.D.; Scortecci, K.C.; Kobashi, L.S.; Agnez-Lima, L.F.; Medeiros, S.R.; Silva, A.A., Jr.; Junqueira-de-Azevedo Ide, L.; Fernandes-Pedrosa Mde, F. Profiling the resting venom gland of the scorpion Tityus stigmurus through a transcriptomic survey. BMC Genomics 2012, 13, 362.

80. Batista, C.V.; Roman-Gonzalez, S.A.; Salas-Castillo, S.P.; Zamudio, F.Z.; Gomez-Lagunas, F.; Possani, L.D. Proteomic analysis of the venom from the scorpion Tityus stigmurus: Biochemical and physiological comparison with other Tityus species. Comp. Biochem. Physiol. C Toxicol. Pharmacol. 2007, 146, 147-157.

81. Batista, C.V.; del Pozo, L.; Zamudio, F.Z.; Contreras, S.; Becerril, B.; Wanke, E.; Possani, L.D. Proteomics of the venom from the Amazonian scorpion Tityus cambridgei and the role of prolines on mass spectrometry analysis of toxins. J. Chromatogr. B Anal. Technol. Biomed. Life Sci. 2004, 803, 55-66.

82. Diego-Garcia, E.; Batista, C.V.; Garcia-Gomez, B.I.; Lucas, S.; Candido, D.M.; Gomez-Lagunas, F.; Possani, L.D. The Brazilian scorpion Tityus costatus Karsch: Genes, peptides and function. Toxicon 2005, 45, 273-283.

83. Barona, J.; Batista, C.V.; Zamudio, F.Z.; Gomez-Lagunas, F.; Wanke, E.; Otero, R.; Possani, L.D. Proteomic analysis of the venom and characterization of toxins specific for $\mathrm{Na}+-$ and $\mathrm{K}+-$ channels from the Colombian scorpion Tityus pachyurus. Biochim. Biophys. Acta 2006, 1764, 76-84.

84. Caliskan, F.; Garcia, B.I.; Coronas, F.I.; Batista, C.V.; Zamudio, F.Z.; Possani, L.D. Characterization of venom components from the scorpion Androctonus crassicauda of Turkey: Peptides and genes. Toxicon 2006, 48, 12-22.

85. Oukkache, N.; Rosso, J.P.; Alami, M.; Ghalim, N.; Saile, R.; Hassar, M.; Bougis, P.E. Martin-Eauclaire, M.F. New analysis of the toxic compounds from the Androctonus mauretanicus mauretanicus scorpion venom. Toxicon 2008, 51, 835-852. 
86. Bringans, S.; Eriksen, S.; Kendrick, T.; Gopalakrishnakone, P.; Livk, A.; Lock, R.; Lipscombe, R. Proteomic analysis of the venom of Heterometrus longimanus (Asian black scorpion). Proteomics 2008, 8, 1081-1096.

87. Diego-Garcia, E.; Peigneur, S.; Clynen, E.; Marien, T.; Czech, L.; Schoofs, L.; Tytgat, J. Molecular diversity of the telson and venom components from Pandinus cavimanus (Scorpionidae Latreille 1802): Transcriptome, venomics and function. Proteomics 2012, 12, 313-328.

88. Luna-Ramirez, K.; Quintero-Hernandez, V.; Vargas-Jaimes, L.; Batista, C.V.; Winkel, K.D.; Possani, L.D. Characterization of the venom from the Australian scorpion Urodacus yaschenkoi: Molecular mass analysis of components, cDNA sequences and peptides with antimicrobial activity. Toxicon 2013, 63, 44-54.

89. Miyashita, M.; Otsuki, J.; Hanai, Y.; Nakagawa, Y.; Miyagawa, H. Characterization of peptide components in the venom of the scorpion Liocheles australasiae (Hemiscorpiidae). Toxicon 2007, 50, 428-437.

90. Silva, E.C.; Camargos, T.S.; Maranhao, A.Q.; Silva-Pereira, I.; Silva, L.P.; Possani, L.D.; Schwartz, E.F. Cloning and characterization of cDNA sequences encoding for new venom peptides of the Brazilian scorpion Opisthacanthus cayaporum. Toxicon 2009, 54, 252-261.

91. Schwartz, E.F.; Camargos, T.S.; Zamudio, F.Z.; Silva, L.P.; Bloch, C.J.; Caixeta, F.; Schwartz, C.A.; Possani, L.D. Mass spectrometry analysis, amino acid sequence and biological activity of venom components from the Brazilian scorpion Opisthacanthus cayaporum. Toxicon 2008, 51, 1499-1508.

92. Rodriguez de la Vega, R.C.; Possani, L.D. Overview of scorpion toxins specific for $\mathrm{Na}+$ channels and related peptides: Biodiversity, structure-function relationships and evolution. Toxicon 2005, 46, 831-844.

93. Chen, J.; Tan, Z.Y.; Zhao, R.; Feng, X.H.; Shi, J.; Ji, Y.H. The modulation effects of BmK I, an alpha-like scorpion neurotoxin, on voltage-gated $\mathrm{Na}(+)$ currents in rat dorsal root ganglion neurons. Neurosci. Lett. 2005, 390, 66-71.

94. Chai, Z.F.; Zhu, M.M.; Bai, Z.T.; Liu, T.; Tan, M.; Pang, X.Y.; Ji, Y.H. Chinese-scorpion (Buthus martensi Karsch) toxin BmK alphaIV, a novel modulator of sodium channels: From genomic organization to functional analysis. Biochem. J. 2006, 399, 445-453.

95. Zhu, S.Y.; Peigneur, S.; Gao, B.; Lu, X.X.; Cao, C.Y.; Tytgat, J. Evolutionary diversification of Mesobuthus alpha-scorpion toxins affecting sodium channels. Mol. Cell Proteomics 2012, 11, M111012054.

96. Mouhat, S.; Andreotti, N.; Jouirou, B.; Sabatier, J.M. Animal toxins acting on voltage-gated potassium channels. Curr. Pharm. Des. 2008, 14, 2503-2518.

97. Ji, Y.H.; Wang, W.X.; Ye, J.G.; He, L.L.; Li, Y.J.; Yan, Y.P.; Zhou, Z. Martentoxin, a novel $\mathrm{K}+-$ channel-blocking peptide: Purification, cDNA and genomic cloning, and electrophysiological and pharmacological characterization. J. Neurochem. 2003, 84, 325-335.

98. Shi, J.; He, H.Q.; Zhao, R.; Duan, Y.H.; Chen, J.; Chen, Y.; Yang, J.; Zhang, J.W.; Shu, X.Q.; Zheng, P.; Ji, Y.H. Inhibition of martentoxin on neuronal BK channel subtype (alpha + beta4): Implications for a novel interaction model. Biophys. J. 2008, 94, 3706-3713. 
99. Yi, H.; Cao, Z.J.; Yin, S.J.; Dai, C.; Wu, Y.L.; Li, W.X. Interaction simulation of hERG K+ channel with its specific BeKm-1 peptide: Insights into the selectivity of molecular recognition. J. Proteome Res. 2007, 6, 611-620.

100. Yi, H.; Qiu, S.; Cao, Z.J.; Wu, Y.L.; Li, W.X. Molecular basis of inhibitory peptide maurotoxin recognizing Kv1.2 channel explored by ZDOCK and molecular dynamic simulations. Proteins 2008, 70, 844-854.

101. Gan, G.L.; Yi, H.; Chen, M.R.; Sun, L.; Li, W.X.; Wu, Y.L.; Ding, J.P. Structural basis for toxin resistance of beta4-associated calcium-activated potassium (BK) channels. J. Biol. Chem. 2008, 283, 24177-24184.

102. Qiu, S.; Yi, H.; Liu, H.; Cao, Z.J.; Wu, Y.L.; Li, W.X. Molecular Information of charybdotoxin blockade in the large conductance calcium-activated potassium channel. J. Chem. Inf. Model. 2009, 49, 1831-1838.

103. Chen, Z.Y.; Hu, Y.T.; Yang, W.S.; He, Y.W.; Feng, J.; Wang, B.; Zhao, R.M.; Ding, J.P.; Cao, Z.J.; $\mathrm{Li}$, W.X.; et al. $\mathrm{Hg} 1$, novel peptide inhibitor specific for Kv1.3 channels from first scorpion Kunitz-type potassium channel toxin family. J. Biol. Chem. 2012, 287, 13813-13821.

104. Han, S.; Yin, S.; Yi, H.; Mouhat, S.; Qiu, S.; Cao, Z.; Sabatier, J.M.; Wu, Y.; Li, W. Protein-protein recognition control by modulating electrostatic interactions. J. Proteome Res. 2010, 9, 3118-3125.

105. Han, S.; Yi, H.; Yin, S.J.; Chen, Z.Y.; Liu, H.; Cao, Z.J.; Wu, Y.L.; Li, W.X. Structural basis of a potent peptide inhibitor designed for Kv1.3 channel, a therapeutic target of autoimmune disease. J. Biol. Chem. 2008, 283, 19058-19065.

106. Yin, S.J.; Jiang, L.; Yi, H.; Han, S.; Yang, D.W.; Liu, M.L.; Liu, H.; Cao, Z.J.; Wu, Y.L.; Li, W.X. Different residues in channel turret determining the selectivity of ADWX-1 inhibitor peptide between Kv1.1 and Kv1.3 channels. J. Proteome Res. 2008, 7, 4890-4897.

107. Cociancich, S.; Goyffon, M.; Bontems, F.; Bulet, P.; Bouet, F.; Menez, A.; Hoffmann, J. Purification and characterization of a scorpion defensin, a $4 \mathrm{kDa}$ antibacterial peptide presenting structural similarities with insect defensins and scorpion toxins. Biochem. Biophys. Res. Commun. 1993, 194, 17-22.

108. Dai, L.; Yasuda, A.; Naoki, H.; Corzo, G.; Andriantsiferana, M.; Nakajima, T. IsCT, a novel cytotoxic linear peptide from scorpion Opisthacanthus madagascariensis. Biochem. Biophys. Res. Commun. 2001, 286, 820-825.

109. Dai, C.; Ma, Y.B.; Zhao, Z.H.; Zhao, R.M.; Wang, Q.; Wu, Y.L.; Cao, Z.J.; Li, W.X. Mucroporin, the first cationic host defense peptide from the venom of Lychas mucronatus. Antimicrob. Agents Chemother. 2008, 52, 3967-3972.

110. Zhao, Z.H.; Ma, Y.B.; Dai, C.; Zhao, R.M.; Li, S.R.; Wu, Y.L.; Cao, Z.J.; Li, W.X. Imcroporin, a new cationic antimicrobial peptide from the venom of the scorpion Isometrus maculates. Antimicrob. Agents Chemother. 2009, 53, 3472-3477.

111. Cao, L.Y.; Dai, C.; Li, Z.J.; Fan, Z.; Song, Y.; Wu, Y.L.; Cao, Z.J.; Li, W.X. Antibacterial activity and mechanism of a scorpion venom peptide derivative in vitro and in vivo. PLoS One 2012, 7, e40135. 
112. Fan, Z.; Cao, L.Y.; He, Y.W.; Hu, J.; Di, Z.Y.; Wu, Y.L.; Li, W.X.; Cao, Z.J. Ctriporin, a new anti-methicillin-resistant Staphylococcus aureus peptide from the venom of the scorpion Chaerilus tricostatus. Antimicrob. Agents Chemother. 2011, 55, 5220-5229.

113. Yuan, W.Y.; Cao, L.Y.; Ma, Y.B.; Mao, P.Y.; Wang, W.P.; Zhao, R.M.; Wu, Y.L.; Cao, Z.J.; Li, W.X. Cloning and functional characterization of a new antimicrobial peptide gene StCT1 from the venom of the scorpion Scorpiops tibetanus. Peptides 2010, 31, 22-26.

114. Cao, L.Y.; Li, Z.J.; Zhang, R.M.; Wu, Y.L.; Li, W.X.; Cao, Z.J. StCT2, a new antibacterial peptide characterized from the venom of the scorpion Scorpiops tibetanus. Peptides 2012, 36, 213-220.

115. Zhao, R.M.; Dai, H.; Qiu, S.; Li, T.; He, Y.W.; Ma, Y.B.; Chen, Z.Y.; Wu, Y.L.; Li, W.X.; Cao, Z.J. SdPI, the first functionally characterized Kunitz-type trypsin inhibitor from scorpion venom. PLoS One 2011, 6, e27548.

116. Chen, Z.Y.; Wang, B.; Hu, J.; Yang, W.S.; Cao, Z.J.; Zhuo, R.M.; Li, W.X.; Wu, Y.L. SjAPI, the first functionally characterized Ascaris-type protease inhibitor from animal venoms. PLoS One 2013, 8, e57529.

117. Chen, Z.Y.; Cao, Z.; Li, W.; Wu, Y. Cloning and characterization of a novel Kunitz-type inhibitor from scorpion with unique cysteine framework. Toxicon 2013, 72, 5-10.

118. Craik, C.S.; Page, M.J.; Madison, E.L. Proteases as therapeutics. Biochem. J. 2011, 435, 1-16.

119. Wang, G.J.; Gao, C.F.; Wei, D.; Wang, C.; Ding, S.Q. Acute pancreatitis: Etiology and common pathogenesis. World J. Gastroenterol. 2009, 15, 1427-1430.

120. Hansen, K.K.; Oikonomopoulou, K.; Li, Y.; Hollenberg, M.D. Proteinases, proteinase-activated receptors (PARs) and the pathophysiology of cancer and diseases of the cardiovascular, musculoskeletal, nervous and gastrointestinal systems. Naunyn Schmiedebergs Arch. Pharmacol. 2008, 377, 377-392.

(C) 2014 by the authors; licensee MDPI, Basel, Switzerland. This article is an open access article distributed under the terms and conditions of the Creative Commons Attribution license (http://creativecommons.org/licenses/by/3.0/). 